\title{
DIGITAL GENEALOGY AND INQUIRY-BASED EDUCATION ICT AT THE PRIMARY SCHOOL
}

\author{
Petr PEXA*, Jihočeská univerzita v Č. Budějovicích
}

Přijato: 13. 8. 2015 / Akceptováno:15. 2. 2016

Typ článku: Teoretická studie

DOI: $10.5507 /$ jtie.2016.005

Abstract: The article represents a possibility of inquiry-based education and realization in education ICT with using a digital genealogy. It is including also a thematic plan and timetable of specific project for use in research in electronic archives in education ICT on secondary school level. The article informs about the possibilities of availing of the internet and digital forms for archival records in genealogical research and the creation of family trees. It describes the different types of registries and there putted registry data and especially presents detailed procedure with digital registries including the possibility to generate various genealogical ascensions and complete website presentation of family tree.

Key words: inquiry-based education ICT, ICT in education, genealogy, family tree, digital archive, registry.

\section{DIGITÁLNÍ GENEALOGIE A BADATELSKY ORIENTOVANÁ VÝUKA INFORMATIKY NA ZÁKLADNÍ ŠKOLE}

Resumé: Článek představuje možnosti realizace badatelsky orientované výuky ve výuce informatiky s využitím digitální genealogie, jeho součástí je i tematický a časový plán konkrétního projektu využití bádání v elektronických archivech ve výuce informatiky na druhém stupni základni školy. Článek dále informuje o možnostech využití internetu a digitálních forem archiválii při genealogickém výzkumu a tvorbě rodokmeni̊. Popisuje jednotlivé druhy matrik a v nich uvedené matrični údaje a především předkládá podrobný postup práce s digitálními matrikami včetně možnosti generování různých genealogických výstupů a kompletni webové prezentace rodokmenu.

Klíčová slova: badatelsky orientovaná výuka ICT, informační a komunikační technologie ve vzdělávání, genealogie, rodokmen, digitální archiv, matrika.

*Autor pro korespondenci: pexa@pf.jcu.cz 


\section{1 Úvod}

Genealogie (řec. génos, lat. genus $=$ rod) je pomocná věda historická, která zkoumá vztahy mezi lidskými jedinci, vyplývající z jejich společného rodového původu. Genealogie se zabývá bud' studiem jednotlivých osobností, nebo sledováním proměn jednotlivých druhů vztahů. Soukromý zájem v této oblasti bývá označován jako rodopis (Hlaváček, Kašpar, Nový, 2002).

$\mathrm{V}$ posledních několika letech je možné sledovat o tuto vědní oblast veliký zájem i ze strany amatérských genealogů a laické veřejnosti, a to nejen díky populárnímu televiznímu seriálu Tajemství rodu, ve kterém pátrají po svých předcích známé české osobnosti, ale především díky fenoménu digitalizace, můžeme pak hovořit o digitální genealogii.

\section{Cíle a metody}

Cílem článku je představit možnosti realizace badatelsky orientované výuky ve výuce informatiky s využitím digitální genealogie a sestavit tematický a časový plán konkrétního projektu využití bádání $\mathrm{v}$ elektronických archivech ve výuce informatiky na druhém stupni základní školy.

Dalším cílem je informovat o možnostech využití internetu a digitálních forem archiválií při genealogickém výzkumu a tvorbě rodokmenů a zpracovat podrobný postup práce $\mathrm{s}$ digitálními matrikami včetně možnosti generování různých genealogických výstupů a kompletní webové prezentace rodokmenu s pomocí volně dostupného software.

Použité metody: analýza kurikulárních dokumentů, komparace a syntéza elektronických forem archiválií, metoda projektového vyučování.

\section{Badatelský orientovaná výuka}

Badatelsky orientovanou výukou (BOV) rozumíme výuku založenou na tzv. bádání (ang. inquiry). Pojem bádání má dlouhou historii, jedno z prvních vymezení tohoto pojmu se objevuje již na začátku 20. století v pracích amerického filozofa, pedagoga a psychologa Johna Deweye: bádání je kontrolovaná nebo řízená transformace neurčité situace v situaci, která je určitá do té míry, nakolik to vyžaduje zařazení prvku původní situace do nějakého jednotného celku (Dewey, 1938).

V současné době se při vymezení pojmu bádání odkazováno na americkou publikaci National Science Education Standards (1996), podle které bádání zahrnuje činnosti žáků, při kterých rozvíjejí své znalosti a porozumění vědeckým myšlenkám. Konkrétně bádání zahrnuje pozorování, kladení otázek, vyhledávání informací v knihách a dalších zdrojích, plánování výzkumu, navrhování postupu zkoumání, využívání nástrojů pro sběr, analýzu a interpretaci dat a sdělování závěrů. Novější verze National Science Education Standards (2000) se problematice bádání věnuje podrobněji a rozlišuje dva typy bádání plné a částečné - podle toho, jakou měrou jsou do něj zapojeni žáci.

V České republice se první zmínka o badatelsky orientované výuce objevuje na portálu RVP v r. 2008, nejprve formou zmínky o tzv. badatelsky orientovaných pedagogických metodách a inquiry-based science education v príspěvku Inovace prírodovédného vzdèlávání $z$ evropského pohledu (Janoušková, Maršák, 2008). V navazujících príspěvcích těchto autorů s podrobnými informacemi o probíhajícím 
evropském projektu Pollen (2006-2009, podpora inovací př́rodovědného vzdělávání spočívající v šíření BOV) a německém národním projektu Sinus transfer (2003-2009, program pro zvýšení efektivity matematického a př́rodovědného vzdělávání) se poprvé objevuje i termín badatelsky orientovaná výuka.

Následně se objevily studie, které bádání specifikují důkladněji, např. Papáček (2010) představil BOV jako směr, který by mohl $\mathrm{v}$ budoucnosti vyřešit krizi př́rodovědného vzdělávání. Stuchlíková (2010) zdůrazňuje význam přesvědčení učitele o potřebnosti změny v realizaci výuky a př́ílonu k BOV, Guskey (2002) uvádí, že učitelovo přesvědčeni o správnosti „inquiry“ je dáno a zpevňováno i tím, že učitel zjišt’uje, že žáci získávají z nových způsobů vyučování více.

Eastwell (2009) uvádí čtyři úrovně bádání, odstupňované podle intenzity zapojení žáka do badatelských aktivit:

- Potvrzující bádání - otázka i postup jsou žákům poskytnuty, výsledky jsou známy, jde o to je vlastní praxí ověřit.

- Strukturované bádání - otázku i možný postup sděluje učitel, žáci na tomto základě formulují vysvětlení studovaného jevu.

- Nasměrované bádání - učitel dává výzkumnou otázku, žáci vytvářejí metodický postup a realizují jej.

- Otevřené bádání - žáci si sami kladou otázku, promýšlejí postup, provádějí výzkum a formulují výsledky.

\section{Je možné využít problematiku digitální genealogie $v$ badatelsky orientované výuce informatiky?}

Výše zmíněné badatelsky zaměřené projekty se věnovaly hlavně př́rodovědnému vzdělávání (biologie, částečně matematiky), ale uvedená vymezení bádání mohou být univerzálně využitelná i ve výuce jiných předmětů, včetně informatiky.

Rámcový vzdělávací program (RVP) pro výuku Informačních a komunikačních technologií (ICT) na druhém stupni základních škol a odpovídajících ročnících víceletých gymnázií stanovuje konkrétní očekávané výstupy a kompetence $\mathrm{v}$ tematických celcích Vyhledávání informací a Zpracování a využití informací. Zmiňme především výstupy:

- Žák ověřuje věrohodnost informací a informačních zdrojů, posuzuje jejich závažnost a vzájemnou návaznost.

- Žák ovládá práci s textovými a grafickými editory i tabulkovými editory a využivá vhodných aplikací.

- Žák uplatňuje základní estetická a typografická pravidla pro práci s textem a obrazem.

- Žák pracuje s informacemi v souladu se zákony o duševním vlastnictví.

- Žák použíá informace $\mathrm{z}$ různých informačních zdrojů a vyhodnocuje jednoduché vztahy mezi údaji.

- Žák zpracuje a prezentuje na uživatelské úrovni informace $\mathrm{v}$ textové, grafické a multimediální formě (webové stránky, prezentační programy, multimédia).

\section{Klíčové kompetence ICT}

- Kompetence k učení: 
o Rozvíjet u žáků dovednosti potřebné k osvojování učiva.

o Prostřednictvím vhodně zvoleného zadání poznat smysl osvojovaných postupů pro běžný život.

○ V týmu i samostatně experimentovat a porovnávat dosažené výsledky.

o Vést žáky k systematickému vyhledávání a ukládání informací.

- Kompetence k řešení problémů:

o Ukázat žákům různé zdroje informací, které vedou k řešení problémů.

o Získávat informace, které jsou potřebné k dosažení cíle.

- Kompetence komunikativní:

o Spolupracovat při řešení ve skupině.

- Kompetence sociální a personální:

o Spolupráce ve dvojici a v malé skupině.

o Stanovovat pravidla pro práci skupiny i samostatnou práci a dodržovat je.

- Kompetence pracovní:

o Naučit se stanovovat si kritéria hodnocení vlastní práce.

Čtyřletá gymnázia - Rámcový vzdělávací program pro výuku Informatiky a Informačních a komunikačních technologií stanovuje tyto očekávané výstupy v tematických celcích Zdroje a vyhledávání informací a Zpracování a prezentace informací:

- Žák využívá dostupné služby informačních sítí $\mathrm{k}$ vyhledávání informací, ke komunikaci, k vlastnímu vzdělávání a týmové spolupráci.

- Žák využívá nabídku informačních a vzdělávacích portálů, encyklopedií, knihoven, databází a výukových programů.

- Žák posuzuje tvůrčím způsobem aktuálnost, relevanci a věrohodnost informačních zdrojů a informací.

- Žák využívá informační a komunikační služby v souladu s etickými, bezpečnostními a legislativními požadavky.

- Žák zpracovává a prezentuje výsledky své práce s využitím pokročilých funkcí aplikačního softwaru, multimediálních technologií a internetu.

Vzdělávací oblast Informační a komunikační technologie tedy umožňuje všem žákům na základních školách dosáhnout základní úrovně informační gramotnosti - získat elementární dovednosti $\mathrm{v}$ ovládání výpočetní techniky a moderních informačních technologií, orientovat se ve světě informací, tvořivě pracovat $\mathrm{s}$ informacemi a využívat je při dalším vzdělávání i v praktickém životě (Rámcový vzdělávací program pro základní vzdělávání, 2005).

Na prvním stupni se žáci seznámí se základními funkcemi počítače a vyzkouší si práci $\mathrm{s}$ operačním systémem, textovým editorem a grafickým editorem $\mathrm{v}$ rámci možností, které jsou přiměřené jejich věku, na druhém stupni si žáci tyto znalosti prohloubí a obohatí o další dovednosti. Naučí se vyhledávat informace na internetu a zpracovávat je ve formě textových či grafických dokumentů, prezentací a jednoduchých internetových stránek.

Vzdělávací oblast Informační a komunikační technologie na čtyřletých gymnáziích navazuje na problematiku probranou v nižších ročnících gymnázia resp. na základní škole a klade si za cíl vychovat žáky ke kritickému přijímání informaci z různých zdrojů a ke kvalitnímu zpracování dokumentů - klasických písemných referátů a seminárních 
prací i multimediálních prezentací. Žáci zvládnou práci $\mathrm{s}$ tabulkami, databázemi, bitmapovou i vektorovou grafikou, animacemi a tvorbu jednodušších webových dokumentů, posledním cílem je naučit žáky logickému myšlení výukou základů algoritmizace úloh (Rámcový vzdělávací program pro gymnázia, 2007).

Získané dovednosti jsou $\mathrm{v}$ informační společnosti nezbytným předpokladem uplatnění na trhu práce i podmínkou k efektivnímu rozvíjení profesní i zájmové činnosti. Zvládnutí výpočetní techniky, zejména rychlého vyhledávání a zpracování potřebných informací pomocí internetu a jiných digitálních médií, umožňuje realizovat metodu „učení kdekoliv a kdykoliv“. Vede k žádoucímu odlehčení paměti při současné možnosti využít mnohonásobně většího počtu dat a informací než v minulosti. Urychluje aktualizaci poznatků a vhodně doplňuje standardní učební texty a pomůcky. Dovednosti získané ve vzdělávacím oboru Informační a komunikační technologie umožňují žákům aplikovat výpočetní techniku $s$ bohatou škálou vzdělávacího softwaru a informačních zdrojů ve všech vzdělávacích oblastech celého základního vzdělávání.

Z uvedených předpokladi̊ tedy vyplývá, že je možnost zařazení problematiky práce $\mathrm{s}$ digitálními genealogickými daty $\mathrm{v}$ rámci Badatelsky orientované výuky předmětu Informační a komunikační technologie velmi vhodná a žáci si dle svých schopností, věku, zájmu a s odbornou pomocí učitele mohou velmi rychle vytvořit alespoň základní rodokmen.

Pro úplnost uved'me i možné zařazení do výuky na školách vysokých - jak již bylo zmíněno v úvodu článku, genealogie je součástí pomocných věd historických, které jsou běžnou součástí výuky ve studijních oborech Historie, Archivnictví apod. na filozofických fakultách českých a moravských univerzit či aprobací s historií na fakultách pedagogických. Aktuálnost popisované problematiky proto dokazuje i zařazení předmětu Výpočetní technika $v$ archivech do studijního programu některých historických oborů na Filozofické fakultě Jihočeské univerzity v Českých Budějovicích a velký zájem o genealogické kurzy $\mathrm{v}$ rámci celoživotního vzdělávání na Univerzitě 3. věku při JU v Českých Budějovicích.

\section{Digitalizace archiválií}

Digitalizace archivních dokumentů byla v České republice zahájena v roce 2007, první digitalizované archiválie - matriky byly veřejnosti $\mathrm{k}$ dispozici v roce 2008 . Průkopníkem byl Státní oblastní archiv v jihočeské Třeboni (https://digi.ceskearchivy.cz).

Postupně se přidávaly další regionální archivy, za všechny zmiňme ještě Zemský archiv v Opavě s digitálním archivem pro Olomoucký a Moravskoslezský kraj (http://www.archives.cz). Odkazy na další oblastní archivy v České republice lze nalézt na webové stránce České genealogické a heraldické společnosti v Praze (www.genealogie.cz/aktivity/digitalizace).

V současné době jsou zcela digitalizovány především české a moravské matriky všech církví a úřadů (jako nejdůležitější materiály pro badatele) a již také soupisy poddaných $\mathrm{z}$ velkostatků. Dokončuje se digitalizace pozemkových knih, s jejichž zveřejněním na internetu je počítáno v r. 2016. 
Dalšími postupně digitalizovanými archiváliemi byly a jsou např. obecní či školní kroniky, mapy, plány, periodika, technické výkresy, sčítací archy vzniklé při sčitáních lidu atd., vše lze nalézt na webové stránce př́íslušného regionálního archivu.

\section{Matriky a jiné dokumenty}

Matriky byly převážně vedeny jednotlivými církvemi, pro běžnou populaci jsou základem především matriky ř́mskokatolické církve. Dále se matriky dělí na knihy narozených (matricula baptisatorum), zemřelých (matricula mortuorum) a oddaných (matricula copulatorum). V mladších dobách byly tyto druhy matričních knih vedeny jako specializované samostatné knihy, ve starších dobách jako knihy společné (Roubík, 1954).

Jak již bylo zmíněno, dalšími zajímavými materiály pro genealogy jsou pozemkové resp. gruntovní knihy, obecní a školní kroniky a především soupisy poddaných. Matriky jsou totiž vedeny až po třicetileté válce, tedy po roce 1648 , ovšem zmíněné soupisy poddaných již cca od r. 1600 a pozemkové knihy dokonce již od 15. st. Pozemkové knihy se vyvinuly z tzv. urbáriou (ty vznikaly koncem 14 . století) a jejich předchůdkyněmi byly tzv. zemské desky, které byly vedeny již od 13. století (Krejčíková, Krejčík, 1987).

\section{Dostupné matriční údaje}

Základem resp. odrazovým můstkem $\mathrm{k}$ úspěšnému vytvoření rodokmenu je vědět alespoň jedno datum a místo narození nějakého předka $\mathrm{v}$ př́slušné př́ímé linii (tedy ze strany otce a matky), a to ideálně před rokem 1900.

Důvodem je fakt, že z důvodu ochrany osobních údajů dosud žijících osob jsou digitalizovány matriky a jiné materiály pouze cca 100 let staré, tedy poslední záznam v konkrétní matrice např. narozených osob musí být starší než 100 let (tzv. skartační lhůta), 75 let pro matriky oddaných a zemřelých. To badání komplikuje, protože matriční knihy jsou často vedeny pro období v rozmezí několika desítek let (Melichar, 1988).

První záznamy v konkrétní knize tedy sice jsou více jak 100 let staré, ovšem poslední již ne a kniha tak na internetu zatím být nemůže, je totiž digitalizována jako celek. Např. v digitálních matrikách Oblastního archivu v Třeboni, kterých je celkem 6875 svazků, lze ale nalézt i matriky zveřejněné z výše uvedených důvodů pouze $\mathrm{z}$ určité části (např. matrika narozených $\mathrm{v}$ obci Lišov $\mathrm{v}$ letech 1893-1907 je zveřejněna zatím z 97\%).

Mladší matriční knihy, které zatím nesplňují skartační lhůtu, deponují př́slušné matriční úřady, které jsou součástí magistrátů a vybraných městských a obecních úruadů.

U každého matričního záznamu o narození (v minulosti byl ale často důležitější a tedy spiše uváděn datum křtu nebo obě data) je pak ještě údaj o rodičích, většinou i prarodičích a mnohdy o partnerovi (doplněno po sňatku). Vždy je tam jméno, př́ijmení a místo narození (resp. pobytu - viz poznámka níže) rodičů a prarodičů, bohužel již téměř nikdy jejich datum narození (prostě proto, že ho nevěděli, nepamatovali si ho, neuměli často číst ani psát). Naopak nechybí profese, ovšem pouze u mužů. Takže nezbývá nic jiného, než vzít matriku př́slušného místa narození (resp. pobytu) rodiče, pokusit se odhadnout alespoň rok narození a pak v knize listovat a listovat. Odhad roku narození je samožrejmě většinou na první pokus chybný a je proto třeba prohlížet matriky \pm 30 let zpátky či dopředu. 
Může se ale při hledání objevit zásadní problém - trvalá a dědičná př́ijmení se tvořila až koncem 16. a v 17. st., do té doby se př́imení přejímala po názvu zakoupeného gruntu (statku). Konkrétně v jižních Čechách tento zvyk přetrvával (i přes zákaz) dokonce až do začátku 19. st. Protože tehdy ještě nebyla ani popisná čísla (byla zavedena až koncem 18. st.), tak existovala jména gruntů (Starý, 2005). Může se tedy stát, že hledání $\mathrm{v}$ dobových matrikách skončí krachem, protože nezachytíme změnu původního příjmení na nové "příjmení" po gruntu, který nositel původního př́ijmení koupil a své př́ijmení z tradice změnil. Takto př̌išel ke svému př́ijmení $i$ rod autora článku - nejstarší předek Urban Graman koupil v r. 1681 Pexovský grunt.

Dalším významným problémem, který se může při genealogickém výzkumu objevit, je použitý jazyk, ve kterém jsou matriky vedeny. $V$ drtivé většině př́padů latinsky, $\mathrm{v}$ různých dobách se pak stř́idavě objevuje němčina, schwabach (resp. jeho psaná forma kurent) a čeština (Maur, 1972). Hlavně s latinou mohou mít mladší ročníky začínajících genealogů ze začátku problém, ale dá se to naučit, lze i využít česko-latinský slovník na stránce http://www.genea.cz/no_cache/informace/slovnicky/latinsko-cesky-slovnicek/.

$\mathrm{V}$ matrikách jsou ale latinské termíny často $\mathrm{v}$ různých zkomoleninách, faráŕi, kteří se v minulosti o matriční záznamy starali, často latinu neovládali dobře. Zase alespoň uměli psát, přesto luštění starších matričních záznamů vyžaduje jisté grafologické zkušenosti.

\section{Tvorba rodokmenu s digitálními materiály}

$\mathrm{Na}$ stránce př́śslušného oblastního archivu si tedy najdeme digitalizované materiály, dále matriky římskokatolické církve, pod př́slušným písmenem vybereme konkrétní obec a pak už máme k dispozici jednotlivé matriční knihy. Matrika $\mathrm{N}$ jsou narození, Z zemřelí, O oddaní, NOZ všichni dohromady. Vybereme tedy knihu podle např. roků narození (Třeboň, Matrika N, 1630-1659) a listujeme po jednotlivých snímcích (stránkách knihy). Př́klad je zvolený z matriky Třeboňského oblastního archivu, v ostatních je struktura položek velmi obdobná.

Najdeme-li tedy konkrétní osobu, u jejího záznamu je uvedeno: kdy a kde se narodila, jak se jmenovali a odkud pocházeli její rodiče (a často i prarodiče, ve starších knihách pouze praotec) a u mužů i profese.

Můžeme tedy pokračovat $\mathrm{v}$ bádání do minulosti - známe jméno a místo narození (resp. pobytu) člověka o generaci zpět, odhadneme rok $\pm 20-50$ let zpátky od narození jeho potomka a hledáme. Opět je nutné připomenout, že matrikáři neevidovali přesný datum narození rodičů, důvody byly zmíněny výše.

Analogicky pracujeme $\mathrm{s}$ knihami zemřelých, oddaných i prastarými soupisy poddaných.

Při hledání ve starších matrikách ze 17. a 18. století můžeme narazit na názvy měsíců v následujících zkratkách - 8bris, 9bris, Xbris. To není osmý, devátý a desátý měsíc, ale desátý, jedenáctý a dvanáctý, při dešifrování autorovi článku pomohlo, že nikde nebyl 11 bris a 12 bris (protože neexistují). Vysvětlení: septem $=$ latinsky sedm, octo $=$ osm, novem $=$ devět, decem $=$ deset. $Z$ toho potom 7 bris $=$ septembris $=$ zárí, 8 bris $=$ ř́ijen, 9 bris $=$ listopad, 10bris nebo často psáno Xbris $=$ prosinec $($ Maur, 1972).

Toto má kořeny ještě $\mathrm{v}$ antice, staří Ř́mané měli nový rok od března a od toho data počítali měsíce, takže např. 10. měsíc byl prosinec (viz juliánský kalendář 
např. na http://www.vsudedobre.cz/kalendar-juliansky/). Část měsíců má název podle čísla, část podle osob (třeba Augustus je podle císaře Augusta, Julius je podle Julia Ceasara atd.).

Další podstatná věc, na kterou je výše odkazováno - obec, uvedená v matričních záznamech u rodičů (resp. prarodičů) hledané osoby, není místo, kde se její rodič či prarodič narodil, ale kde bydlel v době narození svého potomka. Dř́ive se samozřejmě lidé moc nestěhovali za prací (to jsme jako Češi zřejmě zdědili dodnes), takže místo pobytu rodiče nakonec většinou souhlasí i s místem jeho narození.

Autorovi článku se ale v matčině př́ímé linii stalo, že se nejstarší dohledaný předek narodil jinde, než bydlel $\mathrm{v}$ době narození svého prvního dítěte (určité profese se v rámci panství stěhovali, např právě bednáři na dírenském panství Wratislavů v době zakládání pivovarů) a tak bylo bádání v této linii ukončeno v r. 1712 a zatím se nepodařilo najít, kde se matčin prapředek narodil, přestože byly prohledány matriky všech farních úřadů v širokém okolí.

Může se také stát, že v seznamu obcí na stránkách př́slušného oblastního archivu tu "svou" nenajdeme. Je to tím, že ne každá obec měla farní úřad a tak si musíme zjistit, pod který farní obvod ta která obec patřila (týká se především malých obcí). Mapu římskokatolických farností pro tyto př́ípady lze opět nalézt na stránkách př́slušných oblastních archivů (pro Jihočeský kraj např. na http://digi.ceskearchivy.cz/DA?lang=cs\&menu=0\&doctree=1nrA\&id=pages $/ \mathrm{ma}$ pa-rk.php).

$\mathrm{S}$ těmito znalostmi a dostatkem volného času se dá rodokmen sestavit od přibližně roku 1600, autorovi článku to v základních rodičovských (tzv. prímých) liniích trvalo cca půl roku.

\section{Zpracování shromážděných dat}

Na zpracování dat získaných bádáním v matrikách a tvorbu kompletního rodokmenu v počítači lze doporučit český databázový program Ancestry, který je volně $\mathrm{k}$ dispozici na http://ancestry.nethar.com.

Program slouží především k evidenci dat, fotografíi, dokumentů, umí vygenerovat strom rodokmenu, vztahy mezi osobami, rodový vývod, rozrod rodu a vytvářet mnoho dalších genealogických výstupů ve formátech JPG, PDF či SVG.

Program Ancestry obsahuje také velmi kvalitní export všech evidovaných dat do HTML formátu, umí tedy automaticky vytvořit webovou prezentaci celého rodokmenu pomocí vestavěné aplikace Ancestry2html, nabízí i několik předdefinovaných grafických šablon.

\section{Badatelsky orientovaná výuka ICT s využitím digitální genealogie a projektového vyučovaní na 2 . stupni základní školy}

Při sestavení návrhu využití BOV a digitální genealogie ve výuce informatiky bylo využito Eastwellova rozdělení bádání dle intenzity zapojení žáka a zvoleno bádání strukturované - učitel sděluje výzkumnou otázku a navrhuje postup, žáci resp. studenti pak vlastní iniciativou hledají řešení (Eastwell, 2009). Zároveň byla zvolena metoda projektového vyučování. 
Školní vzdělávací program (ŠVP) na fakultní Základní škole Nerudova při Pedagogické fakultě Jihočeské univerzity v Českých Budějovicích stanovuje ve svém ročníkovém učebním plánu výuku předmětu Informační a komunikační technologie

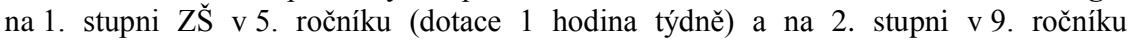
(dotace 1 hodina týdně), vždy ve dvou skupinách po cca 12 žácích.

Kromě toho škola realizuje v 6., 7. i 8. ročníku předmět Využití digitálních technologií v rámci vzdělávací oblasti Člověk a svět práce opět s dotací 1 hodina týdně; na druhém stupni se tedy žáci této školy setkají s informačními technologiemi v každém ročníku 1 hodinu týdně.

Vzdělávací oblast Člověk a svět práce se cíleně zaměřuje na praktické pracovní dovednosti a návyky a doplňuje celé základní vzdělání o důležitou složku, nezbytnou pro uplatnění člověka $\mathrm{v}$ dalším životě a ve společnosti. Tím se odlišuje od ostatních vzdělávacích oblastí a je jejich určitou protiváhou. Je založena na tvưrčí myšlenkové spoluúčasti žáků.

Cílem předmětu Využití digitálních technologií je prohloubit základní znalosti žáků v oblasti informatiky a výpočetní techniky a poskytnout teoretické znalosti a praktické dovednosti, které jsou nezbytné při práci s informacemi a zařízeními výpočetní techniky. Žáci se seznamují s přenosem, uchováním a zpracováním informací, s možnostmi komunikace a prezentací výsledků vlastní práce. Prostřednictvím praktických cvičení si dále rozvíjejí algoritmické myšlení a jsou vedeni $\mathrm{k}$ systematickému př́stupu při řešení problémů.

Očekávané výstupy ŠVP ZŠ Nerudova - Využití digitálních technologií, 8. ročník:

- Žák dokáže najít informace na internetu a využít je pro další práci.

- Žák tř́dí informace a dokáže je zpracovat.

- Žák upravuje obrázky a fotografie $\mathrm{v}$ grafickém editoru, využivá základní nástroje a efekty.

- Žák exportuje dokument do různých grafických formátů.

Očekávané výstupy ŠVP ZŠ Nerudova - Informační a komunikační technologie, 9. ročník:

- Žák vyhledává pomocí prohlížeče informace na internetu, dokáže tyto informace vyhodnotit a publikovat.

- Žák dokáže vytvořit internetové stránky a publikovat je na internetu, využívá pravidla pro správnou volbu obsahu stránky a grafického zpracování.

\section{Návrh realizace projektu BOV a digitální genealogie ve výuce ICT}

$V$ rámci průběžných pedagogických praxí studentů 1 . ročníku navazujícího studia učitelství informatiky na Pedagogické fakultě JU v Č. Budějovicích byl na fakultní ZŠ Nerudova připraven pro žáky 2 . stupně projekt Tvoříme si rodokmen. Po prostudování témat výuky a očekávaných výstupů předmětů Informační a komunikační technologie a Využití digitálních technologií ve Školním vzdělávacím programu ZŠ Nerudova a vzhledem k přiměřenému věku žáků byli cílovou skupinou pro realizaci projektu zvoleni žáci 8. a 9. ročníku.

Zadání projektu pro 8. ročník:

- Téma: Tvoříme si rodokmen. 
- Cíl projektu: vytvoření základního čtyřgeneračního rodokmenu $\mathrm{v}$ př́mých rodičovských liniích, výstupem bude strom rodokmenu ve formátu JPG či PDF.

- Popis projektu: žáci si během prvního týdne zjistí ve spolupráci s rodiči a prarodiči jejich datum a místo narození (př́ípadně i další generaci předkủ), připraví i portrétní fotografie a další dokumenty, tato data pak vloží při výuce ICT do počítače. Následuje seznámení s digitálními matrikami na internetu a dle možností vyhledávání dalších generací. Generování stromu rodokmenu.

- Termín realizace: 2. pololetí školního roku 2015/2016.

- Pomůcky: počítač s internetem, internetový prohližžč, program Ancestry, grafický editor, psací potřeby.

- Časová náročnost: předpokládaná časová dotace je 6 vyučovacích hodin předmětu Využití digitálních technologií a čas pro domácí prrípravu.

- Rozvoj klíčových kompetencí žáků:

o Kompetence $\mathrm{k}$ řešení problémů - žáci řeší problematiku vyhledávání v dosud neznámém prostředí a ovládání nového programu.

- Kompetence pracovní - žáci pracují podle předem daného rozvržení projektu a plánu na zpracování řešení.

○ Kompetence k učení - žáci se učí zorganizovat si svoji práci.

\section{Časový plán projektu pro 8. ročník}

1. vyučovací hodina:

- Zadání projektu, vyučující vysvětlí průběh a cíle projektu.

- Zadání domácí aktivity - zjištění data a místa narození rodičů a prarodičů (případně další generace v závislosti na skartační lhůtě, viz kap. 7).

- Zadání domácí aktivity - př́íprava fotografíi a dalších použitelných dokumentů v elektronické nebo papírové formě.

- Příprava dat bude probíhat 1 týden.

2. vyučovací hodina:

- Seznámení s programem Ancestry, vkládání a editace zjišstěných dat.

3. vyučovací hodina:

- Naskenování papírových fotografíi, úprava v grafickém editoru (žáci tuto problematiku ovládají z výuky v 1. pololetí).

4. vyučovací hodina:

- Vložení fotografíi a dalších připravených dokumentů do Ancestry.

- Generování základního stromu tř́igeneračního rodokmenu pomocí aplikace v Ancestry.

5. vyučovací hodina:

- Seznámení s digitálními matrikami (https://digi.ceskearchivy.cz).

- Na základě předchozích zjištěných údajů o předcích vyhledání čtvrté či další generace v digitální matrice, vložení nalezených dat do Ancestry.

6. vyučovací hodina:

- Generování výsledného stromu rodokmenu, export do JPG či PDF v Ancestry.

Dle zájmu pak mohou žáci sami pokračovat ve vyhledávání v digitálních matrikách o letních prázdninách a rozšírit tak svůj rodokmen před zadáním projektu pro 9. ročník. 


\section{Zadání projektu pro 9. ročník:}

- Téma: Tvoříme si rodokmen - webová prezentace.

- Cíl projektu: vytvoření webové stránky základního rodokmenu v přímých rodičovských liniích.

- Popis projektu: žáci generují pomocí aplikace Ancestry2html z vložených dat webovou prezentaci, po případné úpravě ji umístí na internet.

- Termín realizace: 1. pololetí školního roku 2016/2017.

- Pomůcky: počítač s internetem, internetový prohlížeč, program Ancestry.

- Časová náročnost: předpokládaná časová dotace je 4 vyučovací hodiny předmětu Informační a komunikační technologie.

- Rozvoj klíčových kompetencí žáků:

○ Kompetence $\mathrm{k}$ řešení problémů - žáci řeší problematiku práce v dosud neznámém prostředí a ovládání nového programu.

o Kompetence pracovní - žáci pracují podle předem daného rozvržení projektu a plánu na zpracování řešení.

o Kompetence k učení - žáci se učí zorganizovat si svoji práci.

o Kompetence komunikativní - žáci se zlepšují v komunikaci zejména při závěrečných prezentacích.

○ Kompetence sociální a personální - žáci při závěrečných prezentacích přispívají $\mathrm{k}$ diskuzi.

\section{Časový plán projektu pro 9. ročník}

1. vyučovací hodina:

- Zadání projektu, vyučující vysvětlí průběh a cíle projektu.

- Ukázka aplikace Ancestry2html a hotové prezentace na internetu.

2. vyučovací hodina:

- Generování a úprava vlastní webové stránky rodokmenu v Ancestry2html.

3. vyučovací hodina:

- Vytvoření webhostingového účtu na webzdarma.cz, publikování webové verze rodokmenu.

4. vyučovací hodina:

- Prezentace rodokmenu, hodnocení, diskuse.

Jak je zmíněno v zadání a popisu obou projektů, budou realizovány v 8. ročníku ZŠ ve druhém pololetí stávajícího školního roku resp. v 9. ročníku ZŠ v prvním pololetí školního roku 2016/2017. Vyhodnocení obou projektů a diskuse výsledků tedy proběhne po jejich ukončení v červnu 2016 resp. lednu 2017.

\section{Závěr}

Doposud byly publikovány vědecké články z oblasti badatelsky orientované výuky zaměřené především na př́rodovědné vzdělávání, výuku prŕírodopisu resp. biologie a matematiky. Článek představuje možnost realizace BOV ve výuce informatiky a v rámci mezipředmětových vztahů i ve výuce historie. Na konkrétním projektu nabízí využít bádání velektronických archivech především ve výuce Informačních a komunikačních technologií na druhém stupni základních škol, gymnáziích 
a historických oborech na školách vysokých a tak prakticky realizovat aktuální problematiku badatelsky orientované výuky na téměř všech stupních škol.

V minulosti bylo především velmi časově náročné osobně navštívit regionální (oblastní) archiv za účelem genealogického výzkumu, nebylo také jednoduché se $\mathrm{k}$ takové činnosti vůbec dostat, místa $\mathrm{k}$ bádání $\mathrm{v}$ archivu se rezervovala i rok dopředu. Bylo samozřejmě možné využít genealogů - profesionálů a nechat si rodokmen sestavit, ale to vyžadovalo (a stále vyžaduje) v závislosti na rozsahu (tedy počtu jednotlivých větví) rodokmenu a doplňkové textové dokumentaci finanční investici i v desítkách tisíc korun.

Díky digitalizaci archiválií a jejich zveřejněním na internetu se tedy může genealogickému výzkumu věnovat $\mathrm{v}$ současné době př́mo $\mathrm{z}$ domova téměř každý zájemce nejen v České republice, ale i potomci Čechů a Moravanů z celého světa, kteři pátrají po svých kořenech. Neméně podstatnou výhodou digitalizace archiválií je jistě i jejich ochrana pro budoucí generace.

\section{Literatura}

Dewey, J. (1938). Logic: The theory of inquiry. New York: Holt.

Eastwell, P. (2009) Inquiry learning: Elements of confusion and frustration. The American biology teacher. 71(5), p. 263-264.

Guskey, T. R. (2002) Does it make a difference? Evaluating a professional development. Educational Leadership. Vol. 59. No. 6, pp. 45-51.

Hlaváček, I., Kašpar, J., Nový, R. (2002). Vademecum pomocných věd historických. Praha: $\mathrm{H}+\mathrm{H}$.

Janoušková, S., \& Maršák, J. (2008). Inovace př́rodovědného vzděláváni z evropského pohledu [online]. [cit. 2015-05-19]. Dostupné z: http://clanky.rvp.cz/clanek/o/z/2075/

Krejčíková, J. \& Krejčík, T. (1987) Základy heraldiky, genealogie a sfragistiky. Praha: SPN.

Maur, E. (1972). Vývoj matričního zápisu v Čechách, Historická demografie, 6/1972. Praha, s. 40-58.

Melichar, R. (1988). Sborník k základi̊m genealogie. Praha: Klub pro českou heraldiku a genealogii.

Papáček, M. (2010). Limity a šance zavádění badatelsky orientovaného vyučování prŕrodopisu a biologie v České republice. In Papáček (ed.): Didaktika biologie České republice 2010 a badatelsky orientované vyučování. DiBi. Sborník príspěvků semináre. Jihočeská univerzita: České Budějovice. 145-162 s.

Roubík, F. (1954). Slovniček archivní terminologie. Praha: Archivní správa MV.

Samková, L. (2011) Badatelsky orientované vyučování matematiky [online]. In: Sborník 5. konference Užití počitačů ve výuce matematiky. [cit. 2015-05-19]. Dostupné z: http://home.pf.jcu.cz/ upvvm/2011/sbornik/clanky/36_UPVM11_Samkova.pdf Starý, L. (2005). Váš rodokmen [online]. [cit. 2015-08-01]. Dostupné z: http://rodokmen.blog.cz/.

Stuchlíková, I. (2010). O badatelsky orientovaném vyučování. In Papáček (ed.): Didaktika biologie České republice 2010 a badatelsky orientované vyučování. DiBi 2010. Sbornik přispěvků semináře. Jihočeská univerzita: České Budějovice. 129-135 s.

Wilhelm, K. (1940). Historische Genealogie. München: Oldenbourg. 
Česká genealogická společnost. (2015). [online]. [cit. 2015-08-01]. Dostupné z: http://www.genealogie.cz/.

Family Search, Family History and Genealogy Records. (2015). [online]. [cit. 2015-0801]. Dostupné z: https://familysearch.org/.

GenTeam, Die genealogische Databank [online]. (2015). [cit. 2015-08-01]. Dostupné z: http://www.genteam.at/.

MŠMT.(2005). Rámcový vzdělávací program pro základní vzdělávání. Praha: VÚP.

MŠMT. (2007). Rámcový vzdělávací program pro gymnázia. Praha: VÚP.

National research council. (2000). Inquiry and the national science education standards. Washington, DC: National Academy Press.

Rodokmen od r. 1600. (2015). [online]. [cit. 2015-08-01]. Dostupné z: http://www.petrpexa.cz/rodokmen/.

Státní oblastní archiv v Třeboni. (2015). [online]. [cit. 2015-08-01]. Dostupné $\mathrm{z}$ : http://www.ceskearchivy.czl. 